\title{
1965-1973
}

\section{Social work and human rights: An introduction}

Mike O'Brien

Associate Professor Mike O'Brien is a Life Member and was President of ANZASW 1976-78. Massey University, School of Health and Social Services.

Powles, Guy, Ombudsman. (1968). Guest editorial. New Zealand Social Worker, News and Opinions, 4(4), 3-5.

And

Jack, Miss Avery, (1968). Finland. New Zealand Social Worker, News and Opinions, 4(4), 9-13.
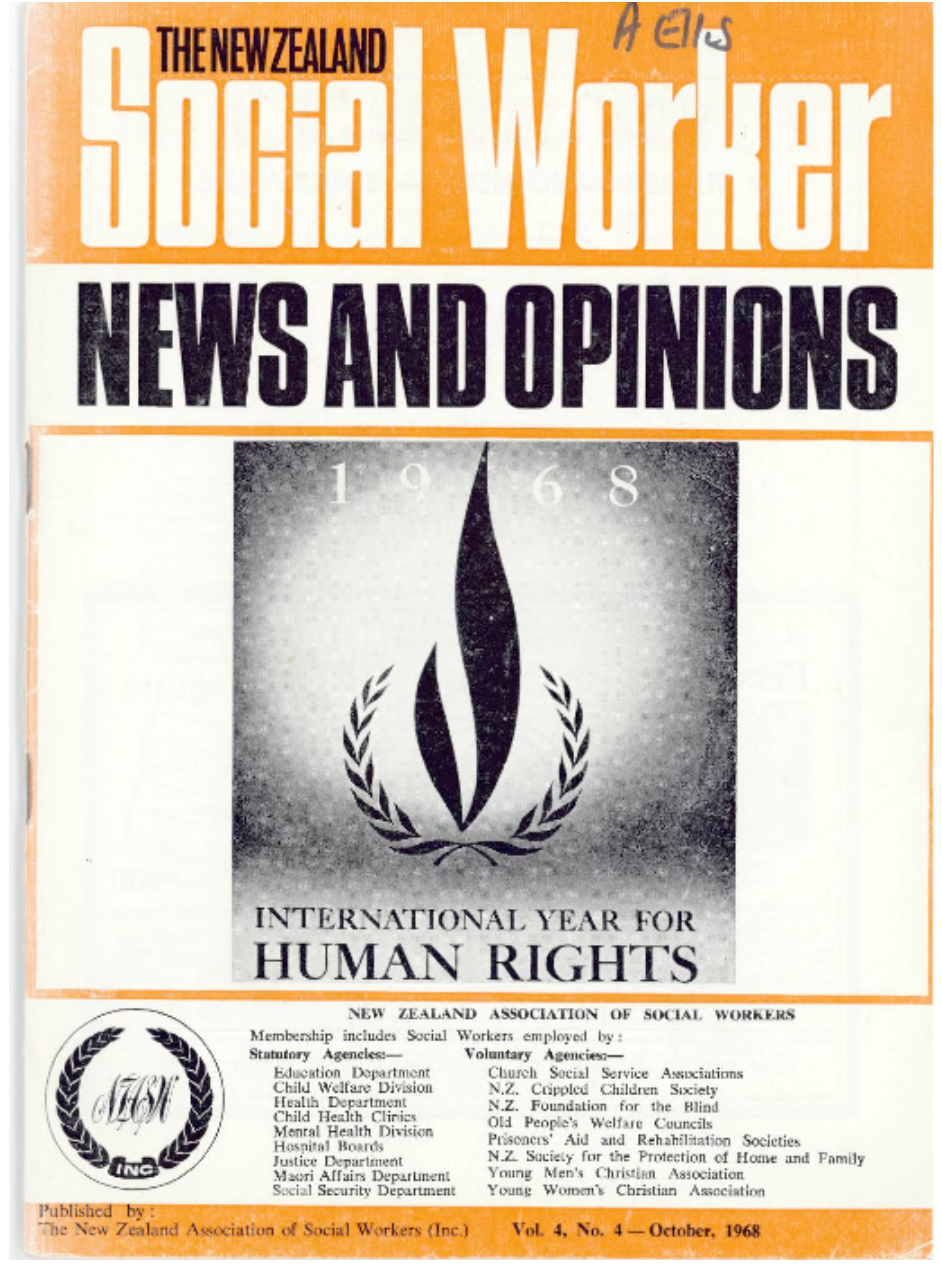
The October 1968 edition of the journal, published in the International Year for Human Rights, contains a series of articles and comments around the human rights theme. The editorial by the then Ombudsman draws attention to economic, cultural and social rights while the summary of that year's IFSW conference refers, inter alia, to the rights of service users. A third article from Errol Braithwaite explores some of the individual human rights issues arising from the growing power of the state in relation to mental health legislation, suggesting, somewhat perversely, that the paternalism which he identifies 'results from the desire for equality'. The perverseness lies in the challenge to the push for greater equality, when extending equality to all citizens is a central human rights goal.

Where is social work and human rights four decades after the publication of this material? Let me take up this question with a series of questions for us to reflect on:

1. How familiar are we with the key human rights documents as they affect what we do - children; disabled people; indigenous people; women; refugees; ethnic minorities; economic, social and cultural rights; political rights?

2. Do we think of clients/users as humans with sets of rights, individually and collectively?

3. Do we limit our thinking about rights to the protection of individual rights or do rights also have a more general application?

4. How do we think about and operationalise the balance between rights and responsibilities? And do responsibilities sit with the powerful or just with the powerless?

5. How actively do we use the ideas and philosophy of human rights in our social work practice?

\section{Guest editorial... \\ Human rights and the social worker}

Sir Guy Powles, Ombudsman

The Charter of the United Nations, the constitutional document of the world community, creates binding obligations for Members of the United Nations with reference to Human Rights.

The human rights provisions of the Charter, although general in character, have the force of positive international law. As such they establish basic duties which all Members must fulfil in good faith. They obligate Member States to co-operate with the United Nations in promoting universal respect for and observance of human rights and fundamental freedoms for all, without distinction as to race, sex, language, or religion.

The inclusion of human rights provisions in the Charter was a revolutionary break with the past; it established unequivocally that human rights are matters of international concern, and that the individual is a subject of international law.

The Universal Declaration of Human Rights, was drawn up by the United Nations Com- 